потребує суттєвого доопрацювання 3 метою повного висвітлення та врегулювання на законодавчому рівні.

Отже, можна зробити висновок, що не всі конституційні положення відображають реальне сучасне становище держави та суспільства, а деякі з них є стратегічними завданнями, які стають перед країною задля формування повної та всебічної демократії, та які спрямовують вектор розвитку держави у процесі подальших державотворчих перетворень 3 метою відповідності сучасному стану цивілізації та реалізації тих цілей державного та суспільного розвитку, які закріплені в Конституції України 1996 року.

\title{
Література:
}

1. Аристотель. Политика. Собрание соч. в 4 т. Т 4. Москва: Мисль, 1984. C. 37-644.

2. Грушевський М.С. Нарис історії Київської землі від смерті Ярослава до кінця 14 сторіччя. Київ, 1991. 560 с.

3. Конституція України: Закон України від 28 червня 1996 р. № 254к/96-ВР/Верховна Рада України. Відомості Верховної Ради України. 1996. № 30. Ст. 141.

4. Петришин О. В. Влада народу - народовладдя: основа демократичної держави . Право України. 2009. № 11. С. 58-65.

DOI https://doi.org/10.30525/978-9934-26-040-7-13

\section{МІСЦЕ СУДОВОГО ПРЕЦЕДЕНТУ У СИСТЕМІ ДЖЕРЕЛ УКРАЇНСЬКОГО ПРАВА}

\author{
Туз A-М. B. \\ студентка II курсу \\ Інституту права
}

Київського начіонального університету імені Тараса Шевченка м. Київ, Україна

В англо-саксонській правовій сім'ї судовий прецедент - це рішення судів загальної юрисдикції по конкретній справі, яке є обов'язковими для нижчестоящих та рівних за рангом судів при вирішенні аналогічної справи. Судові прецеденти відіграють важливу роль у правовому регулюванні, оскільки завдяки їм конкретизуються закони, 
заповнюються прогалини в праві. Такими прецедентами в Україні пропонується визнати рішення Конституційного Суду України та Верховного Суду.

Судовий прецедент має наступні ознаки: 1) є результатом діяльності судової гілки влади та формується в процесі здійснення правосуддя; 2) сформований вищим судом (апеляційним, касаційним тощо), проте вважається прецедентом 3 моменту посилання нижчестоящим судом на правило, сформульоване в ньому; 3)формується при вирішенні конкретного питання в процесі розгляду певної справи; 4) будучи засобом об'єктивізації процесуальних норм, може як встановлювати нову правову норму, так і декларувати або тлумачити вже існуючі норми; 5) поєднує індивідуально-правові та нормативно правові риси; 6) обов'язковість судового прецеденту для судді виникає за умови схожості або подібності справи, яку розглядають, зі справою, в якій існує рішення вищого суду; 7) динамізм та високий ступінь конкретизації процесуальної норми, що об'єктивується в судовому прецеденті [1, с. 10].

За словами В. Сахнюка, прецедент для української правової системи може стати ефективним засобом, який регулюватиме нові суспільні відносини, до яких не встигає пристосуватись правова система та усунути недосконалість, суперечливість та неясність законодавства [2, с. 120].

Як зазначає Д. Кирилюк, систематизоване законодавство не може в умовах соціально-економічного прогресу досягти належного деталізованого та оперативного регулювання нових соціально-економічних інститутів. Конкретні судові справи стають предметом вивчення студентами юридичних ВНЗ та факультетів, а юристи ознайомлюються iз спеціальними бюлетенями судових рішень [3, с. 81]. Це показує процес зближення романо-германської та англосаксонської правових сімей та демонструє дієвість прецедентного регулювання, яке деталізує закон, розкриває його зміст та, базуючись на його нормах, утворює нові правові інститути.

На думку С. Серьогіна, у багатьох країнах світу, зокрема Німеччині, Франції, Швейцарії - по суті в усіх розвинених країнах континентальної правової традиції не заперечується правотворча роль судів. Сучасне континентальне право країн, на які Україна традиційно орієнтується в своєму правовому розвитку, - це не тільки і не стільки кодекси і закони, скільки сотні та тисячі рішень судів різноманітних інстанцій, які стали результатом аналізу обставин конкретних справ, аргументів, покладених в основу попередніх рішень, а іноді тлумачення норм кодексів (законів). Договірне, банківське, податкове право 58 
сучасної континентальної Свропи розвинуте саме у вигляді прецедентів: рішень не тільки вищестоящих, але і регіональних та місцевих судів, що вперше розглядають оригінальний, тобто безпрецедентний спір з визначеного питання [4, с. 12$]$.

Світова судова практика на власному прикладі доводить, що чітко виражений, категоричний, нормативіський підхід до інституту джерел права поступово відходить в минуле.

Система прецедентного права робить прозорою і передбачуваною як судову систему, так і діяльність правоохоронних органів, оскільки будь-який орган чи посадова особа не зможуть за аналогічних обставин відступити від правила, закріпленого в цьому рішенні. За таких обставин втрачає сенс чинити тиск на суд чи будь-яку посадову особу, зменшується кількість скарг і знижується рівень корупції, оскільки ніхто не зможе діяти в аналогічній справі інакше, як у попередній [5, с. 97].

Вагомою перевагою запровадження судового прецеденту як джерела права буде і те, що система прецедентного права, у разі її запровадження, зобов'язуватиме суддів усіх рівнів постійно підвищувати свій професійний рівень та свою компентність, адже кожна зміна або скасування судового рішення автоматично порушуватиме питання про причини допущених помилок і як наслідок призведе до дисциплінарної відповідальності.

До інших важливих приматів існування судового прецеденту можна віднести:

1) Принцип stare decisis («стояти на вирішеному») полегшує роботу суддів та процес здійснення правосуддя. Судді не будуть витрачати свій робочий час на вивчення справ, які вже були предметом розгляду у суді і щодо яких суд уже виносив рішення і матимуть змогу впоратися 3 великим обсягом справ, які потребують судового розгляду.

2) Дотримання принципу stare decisis підвищує рівень легітимності органів судової влади, оскільки громадяни 3 довірою ставляться до відносно стабільного та незмінного в часі судового тлумачення правових норм, що є свідченням неупередженості суддів.

3) Завдяки дії прецеденту право стає більш деталізованим, що дає можливість його гнучкого застосування за нових обставин.

4) Судовий прецедент відкриває шлях до обов'язкового застосування результатів інтелектуальної, а не механічної діяльності суддів у процесі здійснення правосуддя. Особливо це стосується сфери конституційного судочинства, адже саме завдяки прецедентному праву мотивація Конституційного Суду на ціннісних та моральних засадах 
стає загальнообов'язковою, що дає змогу універсалізувати конституційні цінності в межах правової системи.

Запровадження судового прецеденту в Україні $\epsilon$ можливим, оскільки відповідно до ст. 8 Основного Закону нашої держави в Україні визнається та діє принцип верховенства права. У рішенні Конституційного Суду України від 2 листопада 2004 р. (справа про призначення судом більш м'якого покарання) зазначається: «Одним 3 проявів верховенства права $є$ те, що право не обмежується лише законодавством як однією з його форм, а включає й інші соціальні регулятори, зокрема, норми моралі, традиції, звичаї тощо, які легітимовані суспільством і зумовлені історично досягнутим культурним рівнем суспільства. Усі ці елементи права об'єднуються якістю, що відповідає ідеології справедливості, ідеї права, яка значною мірою дістала відображення в Конституції України» [6, с. 21].

Висновок: зважаючи на все вище сказане варто зазначити, що прецедентне право як наближене до конкретних життєвих ситуацій, на відміну від деяких абстрактних норм законодавства, більш адекватно реагує на динамізм сучасного життя, відображаючи правові ідеали i загальновизнані правові цінності, що відкриває певні перспективи застосування прецеденту в Україні як джерела права. Судовий прецедент $€$ одним 3 можливих засобів покращення ефективності роботи судів України, заповнення прогалин в законодавстві та створення єдиної правової позиції при вирішення певної справи в межах всієї країни. Це один зі шляхів інтеграції вітчизняної правової системи до європейського правового простору.

\section{Література:}

1. Луць Л.А. Перспективи становлення судового прецеденту як джерела права України / Л.А. Луць // Вісник Центру суддівських студій. - 2006. - № 6. - С. 10.

2. Сахнюк В.В. Роль та місце судового прецеденту у системі джерел національного права / Сахнюк В.В. // Молодий вчений. 2017. - № 5.1. (45.1). - С. 120.

3. Кирилюк Д. Чи визнається в Україні судовий прецедент? / Д. Кирилюк // Юридичний журнал. - 2006. - № 4. - С. 81.

4. Серьогін С. Судовий прецедент як джерело права в Україні / С. Серьогін // Юридичний портал. - 2015. - № 5. - С. 12.

5. Пошва Б. Судовий прецедент: проблеми запровадження в Україні // Вісник Верховного Суду України. - 2008. - № 9. - С. 97. 
6. Нормативність актів судової влади в англо-саксонській правовій системі: управлінський аспект / I. С. Туркіна // Публічне управління: теорія та практика. - 2013. - Вип. 1. - С. 21.

DOI https://doi.org/10.30525/978-9934-26-040-7-14

\title{
КАТЕГОРИИ «НЕЗАПАМЯТНОЙ ДАВНОСТИ», «ИСКОВОЙ ДАВНОСТИ» И ЗО-ЛЕТНИЙ СРОК КАК ОСНОВА ДЛЯ НЕЗАВИСИМОСТИ И САМОСТОЯТЕЛЬНОСТИ В УПРАВЛЕНИИ УПЦ
}

\author{
Ухтомский А. А. \\ протоиерей, кандидат богословия, \\ преподаватель Истории Европы и Истории Древних Восточных \\ Церквей Киевской Духовной Академии и Семинарии \\ г. Киев, Украина
}

Категории «незапамятной давности» и «исковой давности» регламентируют время наступления и прекращения осуществления права пользования той или иной вещью, имуществом.

Незапамятная давность, характеризует время действия права в течение такого продолжительного срока, что уже никто не помнит, когда произошло его осуществление впервые, «если современники о нем только знают, а о другом не слышали даже и от своих предков» [1, с. 170]. В таком случае предполагается, что это право однажды было приобретено на основании особого законного постановления или на каком-либо правомерном основании [10]. Русский юрист, доктор римского права XIX - XX вв. Давид Давидович Гримм замечает: «Факт осуществления данного права с незапамятных времен освобождает от обязанности доказать, каким образом было приобретено право. Это так называемая незапамятная давность, praescriptio immemorialis или indefinita. Незапамятная давность признавалась римским правом под названием vetustas в известных случаях, она получила дальнейшее развитие в каноническом праве и была распространена практикою на все роды прав» [2, с. 47]

Наряду с незапамятной давностью существует понятие «исковая давность», погашение иска в случае отсутствия, непредъявления его в 